\title{
ANALISIS KINERJA KARYAWAN TERHADAP PRODUKTIFITAS KERJA
}

\author{
Herlina Lusiana \\ Fakultas Ekonomi Uniska Banjarmasin \\ Jl. Adhyaksa No. 2 Kayu Tangi Banjarmasin Kalimantan Selatan \\ e-mail: Lusiana.muyoto@gmail.com
}

\begin{abstract}
Along with the rapid progress in science and technology, indirectly affect the advance of the broadcasting industry, which is a tool of an audio visual information, one of them is TVRI Banjarmasin South Kalimantan station which is a public broadcasting instution under the auspices of the goverment. Competition is quite significant, and TVRI South Kalimantan should pay more attention to the performance of its employees in order to provide expected productivity.The research approach that used by the researcher is a fenomenalogy approach through qualitatif way, with 87 $P N S$ employees and 46 random non PONS respondents. To analyze the employees performance the researcher used five indicators consist of loyalty variable, work performance, responsibility, team work, and initative. To analyze to the work productivity the researcher emphasized on work concentration variable, punctuality of work entry, style of leadership, result of work as expected and level of education, also skilld in completing the work. After collecting data and its process, the result from five respondents of TVRI's employees show that from five performance indicators only two indicators indicate positive value that are loyalty and team work, whereas another three indicator indicate negative value, there are work performance, responsibility and initative. In productivity ony one that shows positive value that is work concentration, while the punctuality of work entry, style of leadership, results of work as expected and level of education, and skills on completing the work show negative value as shown from the result of TVRI South Kalimantan employee respondents.
\end{abstract}

Keywords: Employee performance and work productivity

\begin{abstract}
Abstrak
Seiring dengan kemajuan yang cukup pesat dalam dunia ilmu pengetahuan dan teknologi, secara tidak langsung berpengaruh pada majunya industri penyiaran yang merupakan alat informasi melalui audio visual, salah satunya adalah Stasiun TVRI Kalimantan Selatan yang merupakan lembaga penyiaran publik dibawah naungan pemerintah. Persaingan yang cukup signifikan, membuat TVRI Kalimantan Selatan harus lebih memperhatikan kinerja karyawannya agar dapat memberikan produktivitas yang diharapkan. Pendekatan penelitian yang digunakan penulis adalah dengan suatu pendekatan fenomenologi dengan cara kualitatif, dengan populasi penelitian sebanyak 87 orang karyawan Non PNS dan diambil responden secara acak sebanyak 46 karyawan Non PNS. Untuk menganalisis kinerja karyawan digunakan 5 indikator yang terdiri dari variabel kesetiaan, prestasi kerja, tanggung jawab, kerja sama, dan prakarsa. Setelah proses pengumpulan data dan pengolahannya didapat hasil, dari responden karyawan TVRI Kalimantan Selatan, menunjukkan bahwa dari 5 indikator kinerja hanya terdapat 2 indikator yang menunjukkan nilai positif yaitu kesetiaan dan kerja sama, sedangkan 3 indikator lainnya menunjukkan nilai negatif yaitu prestasi kerja, tanggung jawab dan prakarsa. Pada produktivitas yang menunjukkan nilai positif hanya pada variabel konsentrasi kerja, sedangkan variabel ketepatan waktu masuk kerja, gaya kepemimpinan, hasil pekerjaan sesuai dengan harapan dan tingkat pendidikan keterampilan menunjukkan nilai negatif. Sebagaimana ditunjukkan dari hasil responden karyawan TVRI Kalimantan Selatan.
\end{abstract}

Kata kunci: Kinerja Karyawan dan Produktifitas kerja. 


\section{PENDAHULUAN}

Seiring dengan kemajuan yang cukup pesat dalam dunia ilmu pengetahuan dan teknologi, secara tidak langsung berpengaruh pada majunya industri pernyiaran yang merupakan alat informasi melalui audio visual. Salah satunya adalah TVRI Kalimantan Selatan yang merupakan salah satu lembaga penyiaran publik yang memberikan pelayanan informasi kepada masyarakat. Jika pada perusahaan yang diproduksi adalah barang atau jasa, maka lain halnya TVRI sesuai dengan fungsinya yaitu sebagai alat komunikasi pemerintah. Walaupun berada dalam naungan pemerintah, tetapi TVRI Kalimantan Selatan mengalami persaingan yang cukup signifikan, karena banyaknya berdiri stasiunstasiun televisi swasta yang ikut mewarnai penyiaran televisi ditanah air. Dalam hal ini tentunya diperlukan orang-orang yang ahli dibidangnya seperti kameramen, reporter, teknisi, operator, pengarah acara. Dan mereka dituntut untuk mampu memberikan kontribusi yang optimal dalam penyelenggaraan suatu produksi.

Pada umumnya setiap karyawan memiliki latar belakang dan perilaku yang berbeda dalam pekerjaan yang dapat dilihat dari setiap individu. Perilaku merupakan kata kunci, sebab dalam pekerjaan sangat banyak perilaku yang muncul yang menyebabkan sebuah hasil. Selain itu organisasi juga perlu mengetahui sejauh mana kinerja karyawannya, hal ini dilakukan bukan hanya untuk kepentingan bagi organisasi semata namun juga berguna bagi karyawan yang dinilai,

Peningkatan kinerja karyawan secara perorangan akan mendorong kinerja sumber daya manusia secara keseluruhan, yang direkflesikan dalam kenaikan produktifitas.

\section{Perumusan Masalah}

Dari uraian diatas maka latar belakang dari masalah ini adalah :

1) Bagaimana cara menganalisa kinerja karyawan pada TVRI Kalimantan Selatan.

2) Apakah kinerja karyawan TVRI Kalimantan Selatan dapat meningkatkan produktivitas kerja.

\section{Tujuan dan Manfaat Penelitian}

Dari latar belakang dan perumusan masalah diatas maka penelitian ini bertujuan untuk :

(1)Untuk mengetahui bagaimana kinerja karyawan pada TVRI Kalimantan Selatan.

(2)Sejauh mana kinerja karyawan dapat meningkatkan produktivitas kerja pada TVRI Kalimantan Selatan.

Sedangkan manfaat penelitian ini adalah untuk :

(1) Sebagai bahan bagi TVRI Kalimantan Selatan, guna mengevaluasi dan perencanaan kedepannya agar lebih sukses lagi.

(2) Dapat mendorong bagi karyawan agar meningkatkan kinerjanya.

(3) Bagi penulis, sangat berguna untuk menerapkan ilmu teori dan mengaplikasikannya serta dapat menjadi sumber bagi peneliti lain.

(4) Publikasi ilmiah dalam jurnal lokal yang mempunyai ISSN atau jurnal nasional terakreditasi seperti jurnal .... Universitas Islam Kalimantan (UNISKA).

Pengayaan bahan ajar atau diktat.

\section{TINJAUAN PUSTAKA}

\section{PENELITIAN TERDAHULU}

Penelitian yang dilakukan oleh Fika Yuwana Isbani (2008) tentang pengaruh penilaian kinerja terhadap produktivitas kerja pegawai studi kasus pada Badan Kepegawaian Daerah Kabupaten Simalungun 
bahwa terdapat pengaruh penilaian kinerja terhadap produktivitas pegawai dari perhitungan determinant diperoleh hasil sebesar $13,61 \%$ yang berarti bahwa produktivitas pegawai disebabkan oleh adanya penilaian kinerja, selebihnya $86,39 \%$ dipengaruhi oleh variabel lain yang tidak termasuk dalam penelitian ini, seperti kecerdasan emosional, insentif/bonus, kesehatan dll.

\section{LANDASAN TEORITIS}

a. Pengertian Kinerja

Menurut Anwar Prabu Mangkunegara (2009:67) kinerja adalah secara kualitas dan kuantitas yang dicapai oleh seorang pegawai dalam melaksanakan tugasnya sesuai dengan tanggungjawab yang diberikan kepadanya.

Menurut Wibowo (2010:7) kinerja adalah tentang melakukan pekerjaan dan hasil yang dicapai dari pekerjaan tersebut.

b. Aspek-aspek kinerja

Malayu. S. P Hasibuan. (2006;5) mengemukakan bahwa aspek-aspek yang dinilai kinerja adalah kesetiaan, prestasi kerja, kejujuran, kedisiplinan, kreatifitas, kerjasama, kepemimpinan, kepribadian, prakarsa, kecakapan, dan tanggung jawab.

\section{c. Pengertian Produktivitas Kerja}

Produktivitas kerja adalah suatu ukuran dari pada hasil kerja atau kinerja seseorang dengan proses input sebagai masukan dan output sebagai keluarannya yang merupakan indikator daripada kinerja karyawan dalam menentukan bagaimana usaha untuk mencapai produktivitas yang tinggi dalam suatu organisasi. Muchdarsyah $(2003 ; 16)$

\section{d. Faktor-faktor yang mempengaruhi produktifitas kerja}

Sebagai pribadi dan sebagai karyawan dipengaruhi oleh faktor intern yaitu dalam pribadi karyawan tersebut dan juga faktor ekstern yaitu organisasi. Untuk bisa meningkatkan produktivitas karyawan diperlukan peranan yang sangat besar dari organisasi. Peranan ini dapat diwujudkan dari beberapa bentuk berikut ini seperti fasilitas Kerja, remunerasi, pelatihan dan pendidikan serta situasi kerja.

\section{METODE PENELITIAN}

Menurut jenis penelitian, penelitian ini merupakan penelitian kuantitatif. Metode penelitian yang dipakai adalah metode survey. Dengan metode ini data dikumpulkan berdasarkan jawaban responden atas daftar pertanyaan yang peneliti ajukan melalui pengisian daftar pertanyaan (kuesioner) kepada sejumlah responden. Adapun jenis penelitian ini adalah dengan suatu pendekatan fenomenologi kualitatif yang ditemukan di lapangan kemudian dikembangkan pemahaman secara mendalam dan alamiah.

\section{Pengumpulan Data}

Dalam usaha mengumpulkan data pada penelitian ini adalah sebagai berikut:

\section{a. Library Research}

Yaitu metode pengumpulan data dengan cara membaca literatur-literatur untuk mengetahui lebih mendalam mengenai teoriteori yang berhubungan dengan penulisan ini.

\section{b. Field Research}

Yaitu kegiatan yang dilakukan dengan mengadakan penelitian langsung kelapangan atau perusahaan untuk memperoleh data-data primer yang diperlukan dan juga mengadakan wawancara dengan pimpinan karyawan perusahaan. Pengumpulan data yang dilakukan dengan beberapa cara yaitu :

(1) Wawancara, yaitu pengumpulan data dengan cara mengadakan wawancara 
langsung kepada pimpinan atau karyawan perusahaan.

(2) Kuesioner adalah pengumpulan data dengan terlebih dahulu menyusun daftar pertanyaan yang diajukan kepada responden sehingga arah penelitian atau data-data yang dibutuhkan terarah dan sistematis.

(3) Observasi, adalah pengamatan dilapangan, hal ini bertujuan untuk mendapatkan gambaran umum perusahaan tentang kegiatan kinerja dan fasilitas yang dimiliki oleh TVRI Kalimantan Selatan.

(4) Analisis Data

Data yang berhasil dikumpulkan kemudian dianalisa dengan cara membandingkan dan mengkaji ulang dengan mengggunakan dasar-dasar teoritis yang menjadi acuan penelitian ini untuk mendapatkan pemecahan masalah yang ada serta berguna dalam menarik kesimpulan dan saran yang diberikan.

\section{Variabel Penelitian}

Variabel dalam penelitin ini adalah kinerja, dengan indikator yang merupakan aspek-aspek penilaian kinerja karyawan yang diambil dari DP3 TVRI Kalimantan Selatan, yaitu :

1. Kesetiaan

2. Prestasi Kerja

3. Tanggung Jawab

4. Kerja Sama

5. Prakarsa

Variabel produtivitas, terdiri dari lima pernyataan sebagai berikut :

1. Berusaha untuk berkonsentrasi dalam bekerja.

2. Ketepatan masuk kerja.
3. Pimpinan yang disiplin dan selalu menjaga hubungan baik dengan karyawan.

4. Hasil pekerjaan sesuai dengan harapan.

5. Tingkat pendidikan dan keterampilan membantu dalam menyelesaikan pekerjaan.

\section{Populasi dan Sampel}

Populasi penelitian ini adalah seluruh karyawan non PNS yang bekerja pada TVRI Kalimantan Selatan yang terdiri dari 87 orang dan diambil sampel sebanyak 46 orang - Pemilihan responden dilakukan secara acak dan selama kurun waktu 1 bulan.. Pengambilan jumlah responden dengan menggunakan rumus Slovin :

$$
\mathrm{n} \geq=\frac{\mathrm{N}}{1+\mathrm{Ne}^{2}}
$$

Dimana :

$$
\begin{aligned}
\mathrm{n} \quad= & \text { ukuran sampel } \\
\mathrm{N} \quad= & \text { ukuran populasi } \\
\mathrm{e} \quad & \text { kelonggaran ketidaktelitian karena kesalahan } \\
& \text { pengambilan sampel yang dapat ditoleransi, } \\
& \text { yaitu } 0,1 \% .
\end{aligned}
$$

\section{Teknik Penentuan Skor}

Untuk menentukan skor jawaban responden digunakan skala likert yaitu responden diminta pendapatnya mengenai setuju atau tidak setuju terhadap sesuatu hal. Setiap responden dapat melihat salah satu alternatif jawaban yang tersusun berdasarkan bobot jawaban dengan klasifikasi sebagai berikut :

$\begin{array}{ll}\text { - Sangat setuju } & =5 \\ \text { - } \quad \text { Setuju } & =4 \\ \text { - } \quad \text { Netral } & =3 \\ \text { - } \quad \text { Tidak Setuju } & =2 \\ \text { - } \quad \text { Sangat Tidak Setuju } & =1\end{array}$




\section{HASIL DAN PEMBAHASAN}

\section{Kinerja Karyawan TVRI Kalsel}

Disini peneliti akan memulai untuk melihat secara kualitatif mengenai kinerja karyawan TVRI Kalsel dengan memfokuskan pada 5 indikator yang telah ditentukan, yaitu indikator kesetiaan, prestasi kerja, tanggung jawab, kerjasama dan prakarsa.asil

Dan hasil yang didapat adalah sebagai berikut :

\section{a. Indikator Kesetiaan}

Dari responden sebanyak 46 orang yang merasa nyaman bekerja pada TVRI Kalsel dan menyatakan sangat setuju sebanyak 6 orang (13\%), yang menyatakan setuju sebanyak 18 orang $(39,1 \%)$, yang menyatakan netral sebanyak 16 orang $(34,8 \%)$, yang menyatakan tidak setuju sebanyak 5 orang $(10,9 \%)$, dan yang menyatakan sangat tidak setuju sebanyak 1 orang $(2,2 \%)$.

Dari pernyataan diatas berdasarkan pada rasa nyaman dalam bekerja, maka dapat dikatakan bahwa sebagian besar karyawan merasa nyaman dalam bekerja pada TVRI Kalsel, dibuktikan dengan perbandingan yang cukup jauh antara setuju dan tidak setuju. Rasa nyaman dalam bekerja dikarenakan lingkungan kerja yang nyaman didukung dengan peraturan yang longgar sehingga karyawan merasa nyaman dengan lingkungan kerja tersebut, walaupun ada saja karyawan yang menyatakan netral sebanyak 16 orang $(34,8 \%)$ hal ini dikarenakan karyawan tersebut tidak memiliki cara pandang terhadap suasana kerjanya. Untuk itu pimpinan perlu secara rutin memberikan bimbingan, pengarahan dan berbaur dengan karyawan untuk menambah rasa nyaman karyawan dalam bekerja.

\section{b. Indikator Prestasi Kerja}

Pada indikator prestasi kerja, responden diminta untuk memberikan tanggapannya mengenai hasil pekerjaan yang telah mereka lakukan.

Dapat dijelaskan karyawan yang menyatakan sangat setuju sebanyak 3 orang (6,5\%), karyawan yang menyatakan setuju sebanyak 4 orang $(8,7 \%)$, karyawan yang menyatakan netral sebanyak 18 orang $(39,1 \%)$, karyawan yang menyatakan tidak setuju sebanyak 21 orang $(45,7 \%)$, dan tidak ada karyawan yang menyatakan sangat tidak setuju.

Dari pernyataan diatas mengenai kemampuan dan pengetahuan yang baik dalam indikator prestasi kerja maka dapat dikatakan bahwa karyawan TVRI Kalsel belum memiliki kemampuan dan pengetahuan yang baik

\section{c. Indikator Tanggung Jawab}

Pada indikator tanggung jawab, responden diminta untuk memberikan tanggapannya mengenai tanggung jawab mereka atas pekerjaannya.

Dapat dijelaskan bahwa tidak ada karyawan yang menyatakan sangat setuju, karyawan yang menyatakan setuju sebanyak 13 orang (28,3\%), karyawan yang menyatakan netral sebanyak 12 orang (26,1\%), karyawan yang menyatakan tidak setuju sebanyak 17 orang (37\%), dan karyawan tidak ada karyawan yang menyatakan sangat tidak setuju sebanyak 4 orang $(8,7 \%)$.

Dalam perusahaan dapat dibayangkan jika produksi tidak selesai pada waktu yang telah ditetapkan maka akan terjadi banyak kerugian, begitu juga TVRI Kalsel yang menginginkan semua rencana berjalan lancar 
tanpa adanya penundaan waktu, terutama dalam penyiaran sangat dihindari kegagalan karena bisa berakibat fatal.

\section{d. Indikator Kerjasama}

Pada indikator kerjasama responden diminta untuk memberikan tanggapannya, mengenai sejauh mana kerja samanya kepada rekan kerja lain.

dapat dijelaskan bahwa tidak ada karyawan yang menyatakan sangat setuju, yang menyatakan setuju sebanyak 33 orang (71,7\%), yang menyatakan netral sebanyak 7 orang $(15,2 \%)$, yang menyatakan tidak setuju sebanyak 6 orang $(13 \%)$.

Berdasarkan pernyataan diatas maka dapat dikatakan bahwa karyawan memiliki kerja sama yang baik dengan rekan kerja lainnya, dibuktikan dengan angka tertinggi ada pada karyawan yang menyatakan setuju. Kerjasama merupakan salah satu cara untuk cepat mencapai sebuah tujuan yang diinginkan oleh organisasi, dapat dibayangkan jika dalam suatu perkumpulan tidak terdapat kerja sama tentu tujuan yang diinginkan sulit tercapai.

\section{e. Indikator Prakarsa}

Pada indikator prakarsa responden diminta untuk memberikan tanggapannya mengenai bagaimana prakarsa yang telah mereka berikan untuk TVRI Kalsel.

Dapat dijelaskan bahwa karyawan yang menyatakan sangat setuju sebanyak 2 orang $(4,3 \%)$, karyawan yang menyatakan sangat tidak setuju sebanyak 17 orang (37\%), karyawan yang menyatakan netral sebanyak 27 orang $(58,7 \%)$, dan tidak ada karyawan yang menyatakan setuju dan tidak setuju.

Berdasarkan pernyataan diatas maka dapat disimpulkan bahwa karyawan belum mampu menyelesaikan tugas-tugas baru dengan tanggung jawab yang lebih menantang, dan angka tertinggi ada pada karyawan yang menyatakan netral yang berarti mereka ragu-ragu akan pernyataan tersebut dan kebanyakan mereka yang netral memang belum punya keberanian untuk tugas-tugas baru karena pengetahuan dan keterampilan yang masih terbatas, dan angka tertinggi berikutnya adalah karyawan yang menyatakan sangat tidak setuju, memperjelas bahwa mereka belum siap untuk tugas-tugas yang baru. Dengan tugas-tugas baru tentu memerlukan tingkat pengetahuan dan keterampilan yang berbeda pula, jadi perlu pembekalan yang lebih matang agar dapat diselesaikan dengan baik. Pengetahuan dan wawasan menjadi modal utama dalam menyelesaikan tugas baru, oleh karena itu karyawan perlu menambah pengetahuannya. Dengan didukung teknologi yang serba canggih diharapkan karyawan dapat memanfaatkannya untuk meningkatkan kinerja mereka.

\section{Produktivitas Karyawan TVRI Kalsel}

Disini peneliti akan memulai untuk melihat secara kualitatif mengenai produktivitas karyawan TVRI Kalsel dengan melihat dari 5 variabel yaitu :

\section{a. Selalu Berusaha Untuk \\ Berkonsentrasi Dalam Bekerja}

Dapat dijelaskan bahwa karyawan yang menyatakan sangat setuju sebanyak 4 orang $(8,7 \%)$, yang menyatakan setuju sebanyak 24 orang $(52,2 \%)$, yang menyatakan netral sebanyak 16 orang (34,8\%), yang menyatakan tidak setuju sebanyak 2 orang $(4,3 \%)$, dan tidak ada karyawan yang menyatakan sangat tidak setuju.

Berdasarkan pernyataan diatas maka dapat dikatakan bahwa usahanya untuk berkonsentrasi dalam bekerja cukup baik 
karena angka tertinggi ada pada karyawan yang menyatakan setuju. Suasana yang nyaman dan tentram sehingga mampu menciptakan konsentrasi sangat penting untuk membuat semangat kerja agar bisa fokus pada satu tugas. Bila seorang karyawan tidak mampu berkonsentrasi penuh pada pekerjaannya, maka semangat kerja yang dia miliki akan menjadi sia-sia, karena tidak akan mampu menghasilkan efektivitas dan produktivitas kerja seperti yang diharapkan oleh perusahaan.

\section{b. Ketepatan Waktu Masuk Kerja}

Pada pernyataan ketepatan masuk kerja, responden diminta untuk memberikan tanggapannya, Dapat dijelaskan bahwa karyawan yang menyatakan sangat setuju sebanyak 1 orang $(2,2 \%)$, yang menyatakan setuju sebanyak 7 orang $(15,2 \%)$, yang menyatakan netral sebanyak 12 orang $(26,1 \%)$, yang menyatakan tidak setuju sebanyak 19 orang (41,3\%), dan yang menyatakan sangat tidak setuju sebanyak 7 orang $(15,2 \%)$.

Pada pernyataan ketepatan waktu masuk kerja dapat dikatakan bahwa masih banyak karyawan yang masuk kerja tidak tepat waktu, karena angka tertinggi ada pada karyawan yang menyatakan tidak setuju. Ketepatan waktu berkaitan dengan kedisiplinan karyawan, salah satu faktor yang membuat karyawan kurang disiplin adalah aturan yang masih longgar sehingga karyawan merasa aman walaupun datang terlambat. Dengan adanya ketaatan peraturan, atas kesadaran masing-masing yang akan membentuk disiplin diharapkan akan mendorong berkembangnya produktivitas.

\section{c. Senang Bekerja Karena Sikap Pimpinan Yang Disiplin dan Selalu Menjaga Hubungan Baik Dengan Karyawan}

Dapat dijelaskan bahwa karyawan yang menyatakan sangat setuju sebanyak 4 orang $(8,7 \%)$, yang menyatakan setuju sebanyak 8 orang $(17,4 \%)$, yang menyatakan netral sebanyak 19 orang (41,3\%), yang menyatakan tidak setuju sebanyak 13 orang $(28,3 \%)$, dan yang menyatakan sangat tidak setuju sebanyak 2 orang $(4,3 \%)$.

Berdasarkan pernyataan diatas mengenai gaya kepemimpinan, dapat dikatakan bahwa kebanyakan karyawan kurang senang bekerja karena sikap pimpinan yang menurut mereka belum bisa memotivasi karyawan.

Gaya kepemimpinan merupakan salah satu faktor yang mempengaruhi kinerja, kepemimpinan di TVRI Kalsel mengarah pada gaya kepemimpinan yang cenderung bersifat autokrasi dimana pimpinan membuat keputusan secara sepihak, dibutuhkan pemimpin yang mampu berbaur dengan karyawan dan memberikan contoh yang baik agar dapat memberikan cerminan baik dalam sikap disiplin maupun moralitasnya sehingga menjadi panutan bagi karyawan dalam meningkatkan kinerja untuk mencapai tujuan organisasi.

\section{d. Hasil Pekerjaan Sesuai Dengan Harapan}

Dapat dijelaskan bahwa karyawan yang menyatakan sangat setuju sebanyak 2 orang $(4,3 \%)$, sedangkan karyawan yang menyatakan setuju sebanyak 7 orang $(15,2 \%)$, yang menyatakan netral sebanyak 23 orang (50\%), yang menyatakan tidak setuju sebanyak 14 orang $(30,4 \%)$, dan tidak ada karyawan yang menyatakan sangat tidak setuju. 
Berdasarkan pernyataan diatas dapat dijelaskan bahwa hasil kerja yang dilakukan belum sesuai dengan apa yang diharapkan TVRI Kalsel. Ada berbagai faktor yang menjadi penyebab salah satunya adalah tenaga kerja karyawan yang belum ahli dibidangnya, hal ini terkait dengan program pelatihan yang belum dioptimalkan karena hanya diadakan satu tahun sekali dan karyawan yang diikutsertakan juga terbatas, bukan hanya itu dalam produksi acara masih belum dapat memenuhi harapan masyarakat publik, misalnya acara hiburan yang masih tergolong sederhana.

\section{e. Tingkat Pendidikan dan Keterampilan Membantu Dalam Menyelesaikan Pekerjaan}

Dapat dijelaskan bahwa karyawan yang menyatakan sangat setuju 3 orang $(6,5 \%)$, yang menyatakan setuju sebanyak 5 orang $(10,9 \%)$, yang menyatakan netral sebanyak 23 orang $(50 \%)$, yang menyatakan tidak setuju sebanyak 15 orang $(32,6 \%)$, dan tidak ada karyawan yang menyatakan sangat tidak setuju.

Berdasarkan pernyataan diatas dapat dikatakan bahwa kebanyakan karyawan belum merasa terbantu atas keterampilan dan pendidikan yang telah mereka miliki, karena karyawan yang menyatakan tidak setuju lebih banyak dibanding dengan karyawan yang menyatakan setuju, dan angka tertinggi ada pada karyawan yang menyatakan netral dimana mereka merasa ragu-ragu atau biasa saja atas keterampilan dan pendidikan yang mereka miliki. Pendidikan memang membantu dalam menunjang kinerja agar lebih baik lagi karena dengan pendidikan yang tinggi maka pengetahuan akan bertambah luas sehingga mampu melakukan pekerjaan dalam rangka mencapai tujuan organisasi. Pada kenyataannya memang kebanyakan karyawan TVRI Kalsel memiliki tingkat pendidikan SMA atau SMK dan hanya 1 orang sebagai responden yang memiliki tingkat pendidikan S2.

Produktivitas kerja karyawan TVRI Kalsel dapat dikatakan kurang baik karena dari lima variabel hanya terdapat satu variabel yang menunjukkan nilai positif yaitu konsentrasi kerja sedangkan variabel yang lainnya seperti ketepatan masuk kerja, gaya kepemimpinan, hasil pekerjaan sesuai dengan harapan, dan tingkat keterampilan pendidikan menunjukkan nilai yang negatif. Produktivitas kerja karyawan merupakan unsur penting dalam sebuah organisasi, dengan produktivitas yang rendah maka hasil yang akan didapat dari kinerja karyawan ini juga rendah. Namun produktivitas ini sifatnya fluktuatif. Hal ini ditentukan oleh kondisi produktivitas individu tersebut dalam organisasi.

\section{KESIMPULAN DAN SARAN Kesimpulan}

Berdasarkan hasil penelitian dan pembahasan di atas dapat disimpulkan beberapa hal yang terdiri dari

1. kinerja karyawan TVRI Kalsel yang diukur dari beberapa indikator yaitu kesetiaan, prestasi kerja, tanggung jawab, kerja sama, dan prakarsa, dapat disimpulkan bahwa terdapat beberapa indikator yang relevan atau menunjukkan nilai positif yaitu pada indikator kesetiaan dan kerja sama, sedangkan indikator yang tergolong tidak relevan atau menunjukkan nilai negatif yaitu prestasi kerja, tanggung jawab, dan prakarsa.

2. Produktivitas karyawan diukur dari lima variabel yaitu, konsentrasi kerja, ketepatan waktu masuk kerja, pimpinan yang disiplin dan menjaga hubungan baik 
dengan karyawan, hasil pekerjaan sesuai dengan harapan, tingkat pendidikan dan keterampilan. Dari lima variabel tersebut, hanya terdapat satu variabel yang relevan yaitu selalu berusaha untuk berkonsentrasi dalam bekerja, sedangkan pada variabel lainnya tergolong tidak relevan yaitu pada variabel ketepatan masuk kerja, pimpinan yang disiplin dan menjaga hubungan baik dengan karyawan, hasil pekerjaan sesuai dengan harapan dan tingkat pendidikan keterampilan.

\section{Saran}

Berdasarkan pada serangkaian proses penelitian yang telah dilalui oleh penulis, maka berdasarkan kondisi tersebut penulis mengajukan beberapa saran sebagai berikut :

1. Untuk meningkatkan kinerja karyawan TVRI Kalsel, diperlukan motivasi terhadap karyawan seperti memberikan sarana dan prasarana yang lebih baik lagi secara kualitas maupun kuantitas dan juga penghasilan karyawan yang diharapkan sesuai dengan beban kerja dan kebutuhan hidup.

2. Program pendidikan dan pelatihan perlu diupayakan sehingga semua karyawan dapat diikutsertakan, dengan harapan karyawan dapat menggali potensinya dan diaplikasikan untuk meningkatkan produktivitas secara nyata.

3. Diharapkan adanya perubahan gaya pimpinan agar lebih demokrasi bukan autokrasi, dimana gaya pimpinan yang demokrasi selalu melibatkan karyawan dalam setiap pengambilan keputusan sehingga karyawan merasa dihargai dan secara tidak langsung akan membuat situasi kerja lebih nyaman karena pimpinan mampu berbaur dengan karyawan.
4. Peraturan pada TVRI Kalsel diharapkan lebih dipertegas terutama dalam ketepatan waktu masuk kerja, sehingga dapat menciptakan kedisiplinan menuju sikap profesional. Dengan adanya peningkatan ketaatan tenaga kerja merupakan priorotas utama dalam rangka peningkatan loyalitas kerja pada TVRI Kalsel.

\section{DAFTAR PUSTAKA}

Anwar Prabu Mangkunegara (2000:67), Manajemen Sumber Daya Manusia Perusahaan.

Heidjrachman Ranupandojo dan Suad Husnan Manajemen Personalia" (1984:122-127)

Husein Umar, 2008, Desain Penelitian MSDM dan Perilaku Karyawan: Paradigma Positivistik dan Berbasis Pemecahan Masalah, Ed.1-1, PT Raja Grafindo Persada, Jakarta.

Malayu SP Hasibuan, 2003, Manajemen Sumber Daya Manusia, STIE YKPN, Yogyakarta.

Nitosemito, 1992, Manajemen Personalia, Ghalia Indonesia, Jakarta.

Prof. dr. Wibowo, S.E., M.Phil, 2007 Manajemen Kinerja, Ed.3, PT Raja Grafindo Persada, Jakarta.

Rivai, Veithzal "Performance apprasial, PT Raja Grafindo, Persada Jakarta : 2005

Robbins, Stephen P.; Judge, Timothy A., 2008. Perilaku Organisasi Buku 1, Salemba Empat, Jakarta.

Sondang P Siagaian, 2001, Manajemen Sumber Daya Manusia, Edisi ke 1 Cetakan Ketiga, PT. Bima Aksara, Jakarta.

T. Hani Handoko, 1987, Manajemen Personalia dan Sumber Daya Manusia. BPFE: Yogyakarta.

Triton, PB, 2009, Mengelola Sumber Daya Manusia, Oryza, Yogyakarta. 